\title{
ОСОБЛИВОСТІ ФУНКЦІОНУВАННЯ АМІАКОПРОВОДУ В СТРУКТУРІ ТРУБОПРОВІДНОГО ТРАНСПОРТУ МИКОЛАЇВСЬКОГО РЕГІОНУ
}

\author{
Спатар Олександр Володимирович \\ інженер з метрології \\ державне підприємство «Укрхімтрансаміак \\ Kot2813028@gmail.com
}

У статті досліджено особливості функціонування аміакопроводу в структурі трубопровідного транспорту Миколаївської області. Виконано аналіз екологічної безпеки та надійності експлуатації лінійної частини магістрального аміакопроводу підприємства «Укрхімтрансаміак». Визначено, що для забезпечення безпечних режимів роботи магістрального аміакопроводу передбачено автоматизовану систему управління технологічним процесом транспортування рідкого аміаку на базі електронних засобів контролю та мікропроцесорної техніки.

Ключові слова: розвиток трубопровідного транспорту, транспортування аміаку, магістральний аміакопровод, регіональні особливості.

DOI: https://doi.org/10.32845/bsnau.2019.3.23

Постановка проблеми у загальному вигляді та її зв'язок із важливими науковими чи практичними завданнями. Розвиток продуктивних сил України супроводжується збільшенням потужностей технологічних комплексів, транспортних засобів, енергетичних систем, вузлів управління. Однак не всі елементи техносфери мають належну стійкість і надійність експлуатації в нормальних умовах роботи, тому існує небезпека виникнення надзвичайних техногенних ситуацій та катастроф. Особливою потенційною небезпекою є будівництво і розвиток об'єктів, що транспортують, зберігають або використовують радіоактивні, сильнодіючі отруйні, вибухово- та пожежонебезпечні речовини. Навіть невеликі аварії здатні викликати порушення герметичності ємностей і комунікацій, що у свою чергу може призвести до людських жертв і тяжких екологічних наслідків. Аміакопровід «Укрхімтрансаміак» $є$ безперервною трубою, уздовж якої розміщуються інженерні споруди, що забезпечують перекачування аміаку за наперед заданими параметрами. Аміакопровід призначено для транспортування рідкого аміаку (NH3) від ПО «Тольятіазот» на Одеський припортовий завод для подальшої поставки його на експорт, а також для видачі його по трасі сільськогосподарським споживачам.

Аналіз останніх досліджень і публікацій, в яких започатковано розв'язання даної проблеми і на які спирається автор, виділення невирішених раніше частин загальної проблеми, котрим присвячується означена стаття. Розвиток транспортної галузі в частині специфіки діяльності трубопровідних мереж досліджується в працях багатьох вчених. Із проаналізованих робіт О. М. Адаменка, С. І. Дорогунцова, Л. Г. Мельника, Г. І. Рудька, В.М. Шмандія, D. R. Baer, R. D. Cane та ін. слідує обмеженість інформації щодо особливостей функціонування на регіональному рівні окремих видів трубопровідного транспорту. Особливої уваги викликає дослідження аміакопроводу в структурі трубопровідного транспорту, що $є$ важливим стратегічним елементом розвитку транзитної функції країни.

Формулювання цілей статті (постановка завдання). Метою статті $€$ дослідження впливу регіональних чинників на розвиток аміакопроводу в структурі трубопровідного транспорту Миколаївської області. У межах досягнення мети виокремлено наступні завдання: здійснити аналіз екологічної безпеки та надійності експлуатації лінійної частини

магістрального аміакопроводу підприємства «Укрхімтрансаміак»; дослідити необхідність забезпечення безпечних режимів роботи магістрального аміакопроводу і передбачити автоматизовану систему управління технологічним процесом транспортування рідкого аміаку.

Виклад основного матеріалу дослідження 3 повним обґрунтуванням отриманих наукових результатів. Трубопровідний транспорт Миколаївської області представлений Миколаївським управлінням магістрального аміакопроводу «Укрхімтрансаміак», що здійснює транзит рідкого аміаку по території України. Довжина магістрального трубопроводу, що обслуговується підприємством, становить 444 кілометрів. Технічна можливість для транспортування рідкого аміаку - до 3 млн. тонн на рік [1].

Загальна довжина аміакопроводу складає 2417 км, 3 них по Україні - 1018 км. Територія аміакопроводу, що проходить по Україні, поділяється на управління: Придніпровське (ПУМА), Миколаївське (МУМА). Довжина ділянки, що обслуговується ПУМА УДП «Укрхімтрансаміак» складає - 577,416 км. Магістральний аміакопровод складається з наступних основних інженерних споруд: лінійна частина - магістральний трубопровід із секціонуючою арматурою; насосні станції (НC) (головні, проміжні та кінцева); роздавальні станції (РС); пости секціонування; установки електрохімічного захисту (ЕХ3); електроустановки і лінії електропередачі; засоби автоматизації; лінії і споруди технологічного зв'язку; центральні ремонтні бази та інші споруди, що призначені для поточного обслуговування траси, проведення профілактичного ремонту і ліквідації аварійних ситуацій та аварій [2].

Максимальна кількість аміаку, що транспортується через Миколаївський регіон, дорівнює 120 т/год. Максимальна кількість аміаку, що транспортується, дорівнює 316 т/год. Магістральний аміакопровод прокладено далеко від міст, транспортних і промислових вузлів, в обхід територій заповідників і заказників, родовищ корисних копалин і районів 3 несприятливими інженерно-геологічними умовами. Охоронну зону магістрального аміакопроводу встановлено на 1000 м по обидва боки від його осі. 3 метою запобігання випадкових пошкоджень трубопроводу його прокладено під землею на глибині не менше 1,4 м до верху труби на суші й 0,5-1,4 м на переходах через водні перешкоди, за винятком переходу через Дніпро, де він проходить по мостовому переходу над водою. Траса аміакопроводу маркірується на місцевості легко 
помітними кілометровими знаками, які встановлюються на відстані 5 м від осі трубопроводу. Аміакопровод при перехрещенні з іншими трубопроводами та кабелями прокладено нижче цих трубопроводів та кабелів [3].

Зовнішні поверхні трубопроводу і кожуха покрито ізоляційним матеріалом, а для запобігання корозії внутрішньої поверхні кожуха міжтрубний простір заповнено азотом. Для підвищення надійності на підводних, надводних, автомобільних і залізничних переходах товщину стінки внутрішнього трубопроводу збільшено в 1,5 рази. Для зменшення кількості аміаку, що витікає у разі розриву труби, лінійна частина аміакопроводу була розділена на секції постами секціонування. На Миколаївській ділянці аміакопровод розділено постами секціонування в середньому через 9 км. В якості запірної арматури для відключення секції використовуються кульові крани з електропневмогідравлічним приводом, що мають рівнопрохідний з трубопроводом діаметр [4].

Під час експлуатації трубопроводу є вірогідність виникнення аварійних зупинок насосів, зниження тиску на одній з ділянок трубопроводу в ситуаціях розриву трубопроводу або тоді, коли напрям потоку середовища змінюється на зворотний. Щоб запобігти такій ситуації, застосовуються зворотні клапани. Вони пропускають потік робочого середовища лише в тому напрямку, яке потрібне. Для забезпечення безпечних режимів роботи магістрального аміакопроводу передбачено автоматизовану систему управління технологічним процесом транспортування рідкого аміаку на базі електронних засобів контролю та мікропроцесорної техніки. Аміакопровод обладнано самостійною системою телефонного і радіозв'язку. Для оперативного виявлення можливого витоку аміаку і вживання захисних заходів передбачають автоматичний постійний вимір значень тиску рідкого аміаку і витрати рідкого аміаку на насосних станціях. Відключення аварійних ділянок здійснюють автоматичним закриттям кульових кранів на постах секціонування при тиску рідкого аміаку нижче за значення, передбаченого проектною документацією [2].

У недалекому минулому роль і значення експорту як індикатора конкурентоспроможності країни на міжнародному ринку була істотно недооціненою. По цілому ряду товарних позицій Україна почала поступатися своїми ринками іншим виробникам. Ось, наприклад, як це відбувалося за найважливішою експортною хімічною позицією - аміаком. Цей продукт виробляється приблизно в 60 країнах світу. Але основні світові виробники - постачальники аміаку на світовий ринок були зосереджені на Близькому Сході і в Карибському басейні. Обсяг світової торгівлі аміаком оцінювався в 19-20 млн. тон на рік. Україна разом з Тринідадом і Тобаго, Росією, США, Індонезією, країнами Близького Сходу входила в десятку найбільших гравців світового ринку аміаку. Шість заводів у Рівному, Дніпродзержинську, Горлівці, Сєвєродонецьку, Південному, Черкасах в докризовий період виробляли понад 5 млн. тон продукту, майже третина з якого йшла на експорт. Частка України у світовій торгівлі аміаком становила $8 \%$.

На жаль, на сьогоднішній день великого постачальника аміаку на зовнішній ринок під назвою «Україна» немає. Експортна позиція країни по аміаку втрачена. Хімпідприємства товарний аміак практично не виробляють. Сумно, але мільйони доларів, виручені за цей продукт, пішли повз нашої держави. Однак у нашої країни не відняти головного - її транзитного потенціалу. Сьогодні аміакопровод Тольятті -
Одеса на 70\% завантажений іноземною сировиною, і держава Україна продовжує отримувати прибуток від транзиту, зберігання і перевалки аміаку по трубі і в Одеському порту [5, c. 34].

"Укрхімтрансаміак" активно співпрацює з іноземними виробниками аміаку, трейдерами і судновласниками. Серед партнерів - швейцарська Nitrochem distribution, французька Transammonia, американська IBE Corp., норвезька Yara і багато інших. Зараз Україна залишається найбільшим транспортним посередником на світовому ринку при продажі аміаку. Одним з основних фракторів зацікавленості іноземних виробників і постачальників аміаку $є$ вигідне логістичне розташування України. Та ж Росія, на частку якої припадає близько $18 \%$ світового експорту аміаку, основну його частину транспортує по українській трубі. УДП «Укрхімтрансаміак» своєчасно і в повному обсязі виконує свої зобов'язання в рамках підписаних міжнародних контрактів з транспортування і транзиту аміаку [6]. Тобто, незважаючи на зниження або навіть повну зупинку виробництва товарного аміаку в Україні, на роботу аміакопроводу це майже не вплине.

Відмовитися від випуску мінеральних добрив Україна не може, скільки б не коштував газ. Ціна газу - це стимул для диверсифікації виробництв і зниження енергоспоживання. Але без хімічних добрив немає ефективного сільського господарства. Питання забезпечення аграрною продукцією населення безпосередньо пов'язане з кількістю і якістю вироблених в Україні добрив. Втрата внутрішнього ринку міндобрив - удар по національних інтересах. А значить, в будьякому випадку ми будемо змушені підтримувати і розвивати вітчизняну хімію. Вітчизняні сільгосппродукти починаються 3 хімічної промисловості та ринку добрив [7].

"Укрхімтрансаміак" - це не тільки транспортне підприємство, а й оператор видачі аміаку сільгоспвиробникам. До 1989 року аміакопровод через роздавальні станції по всій своїй довжині видавав понад 200 тис. тон рідкого аміаку. Сьогодні намагаються відновити цей напрямок діяльності, тобто відновити роботу роздавальних станцій - в рік виходять на видачу близько 4 тис. тон аміаку, і попит на такі послуги постійно зростає. Тобто перспектива у цього напрямку - величезна. Як і вигода для сільгоспвиробника, який отримує «свіжоспечений» аміак прямо з труби, без зайвих транспортних витрат і посередників. Послугами роздавальних станцій з видачі аміаку користуються в Полтавській, Харківській, Дніпропетровській, Хмельницькій, Вінницькій, Кіровоградській областях, а з весни цього року - також аграрії Черкаського, Миколаївського та Одеського регіонів [8, с .6].

Українська сторона управляє тільки частиною аміакопроводу, приблизно половиною. Друга частина труби знаходиться на території іншої держави. Єдиний технологічний комплекс розділений за принципом оперативного управління і технічних заходів на дві складові, одна з яких контролює російське підприємство «Трансаміак», іншу - компанія "Укрхімтрансаміак". Кожне з них має свої виробничі плани, плани ремонтів, капітальних і поточних. Стратегія 2020 року Миколаївської області ставить перед собою надзвичайно важливе завдання - перетворити Миколаївщину на регіон сталого економічного зростання на основі інноваційної промисловості, розвинутого транспортно-логістичного комплексу, важливий продовольчий центр країни з екологічним, високоесрективним сільським господарством, комфортний та безпечний край, де 
$€$ всі умови для всебічного розвитку людини. Цьому сприятиме перш за все розвиток аміакопроводу. Впровадження інноваційних технологій, впровадження енергозберігаючих систем, впровадження сонячних і вітряних генераторів на підприємстві як однієї зі складових зниження вартості перекачування. Надлишки виробленої електроенергії $€$ додатковим джерелом доходу від продажів за зеленим тарифом. На території Миколаївської області реалізується ряд проектів по будівництву сонячних електростанцій. Впровадження сонячних і вітряних генераторів призведе до появи додаткових робочих місць.

Висновки з даного дослідження і перспективи подальших розвідок у даному напрямку. Таким чином, впровадження інноваційних заходів, нововведень допоможе розвиватися Миколаївському регіону як осередку сталого економічного розвитку. Збільшення обсягів видачі аміаку пояснюється насамперед інтенсивним розвитком аграрної сфери. Згідно зі статистичними даними, вітчизняне сільське господарство це єдина галузь в Україні, яка постійно розвивається. I аграрії, які впродовж останніх років все активніше впрова- джують нові методи та технології, мають потребу у ефективних шляхах підживлення ґрунту. Тому попит на внесення рідкого аміаку рік за роком стабільно зростає. У той же час варто зауважити, що наші фахівці вчасно та у повному обсязі технічно підготували роздавальні станції трубопроводу, які розташовані вздовж усієї ділянки аміакопроводу, до початку сезону видачі аміаку.

Автором стверджується думка про те, що стратегія 2020 року Миколаївської області ставить перед собою надзвичайно важливе завдання - перетворити Миколаївщину на регіон сталого економічного зростання на основі інноваційної промисловості, розвинутого транспортно-логістичного комплексу, важливий продовольчий центр країни з екологічним, високоефективним сільським господарством, комфортний та безпечний край, де $є$ всі умови для всебічного розвитку людини. Зауважено, що впровадження інноваційних технологій, впровадження енергозберігаючих систем, впровадження сонячних і вітряних генераторів на підприємстві як однієї зі складових зниження вартості перекачування, сприятиме розвитку аміакопроводу.

\section{Список використаної літератури:}

1. Стратегія розвитку Миколаївської області на період до 2020 року URL: https://docviewer.yandex.ua/view/0/?page

2. Технологічний регламент транспортування рідкого аміаку магістральним трубопроводом по території України: місцевий контроль, сигналізація, захисні блокування, автоматичне регулювання насосних станцій. Українське державне підприємство «Укрхімтрансаміак». Чинний до 2010 р. Київ.

3. Магистральные трубопроводы для транспортирования жидкого амиака (амиакопроводы). Правила технической эксплуатации: ГСТУ 3-041-2003. [Действующий от 2003-30-10]. К.: Минпромполитики Украины, 2003.

4. Розрахунково-пояснювальна частина до Декларації безпеки об'єктів підвищеної небезпеки УдП «Укрхімтрансаміак» Магістральний аміакопровід «Тольяті-Одеса» та його відгалуження «Горлівка-Лозова»: Кн. 1 Об- ґрунтування фізіко-математичних моделей і методів розрахунку. Дніпродзержинськ. 2010 р.

5. Белозеров Г. А. Выбор уставок аммиачных газосигнализаторов. Холодильная техника. 2006. № 5. С. 34 - 37

6. ДП «Укрхімтрансаміак» почав обстеження стану магістралі аміакопроводу URL: https://infoindustria.com.ua/dpukrhimtransamiak-pochav-obstezhennya-stanu-magistrali-amiakoprovodu/

7. Как работает самый длинный в мире аммиакопровод? URL: https://www.popmech.ru/technologies/254552-kak-rabotaetsamyy-dlinnyy-v-mire-mmiakoprovod/

8. Бондаренко В. Л. Перспективы получения редких газов из отдувочных потоков производства аммиака. Холодильная техника. 2007. № 2. С. 5 -9.

1. Stratehiia rozvytku Mykolaivskoi oblasti na period do 2020 roku URL: https://docviewer.yandex.ua/view/0/?page

2. Tekhnolohichnyi rehlament transportuvannia ridkoho amiaku mahistralnym truboprovodom po terytorii Ukrainy: mistsevyi kontrol, syhnalizatsiia, zakhysni blokuvannia, avtomatychne rehuliuvannia nasosnykh stantsii. Ukrainske derzhavne pidpryiemstvo «Ukrkhimtransamiak». Chynnyi do 2010 r. Kyiv.

3. Mahystralnыe truboprovodы dlia transportyrovanyia zhydkoho amyaka (amyakoprovodы). Pravyla tekhnycheskoi эkspluatatsyy: HSTU 3-041-2003. [Deistvuiushchyi ot 2003-30-10]. K.: Mynprompolytyky Ukraynb, 2003.

4. Rozrakhunkovo-poiasniuvalna chastyna do Deklaratsii bezpeky obiektiv pidvyshchenoi nebezpeky UDP «Ukrkhimtransamiak» Mahistralnyi amiakoprovid «Toliati-Odesa» ta yoho vidhaluzhennia «Horlivka-Lozova»: Kn. 1 Ob- gruntuvannia fiziko-matematychnykh modelei i metodiv rozrakhunku. Dniprodzerzhynsk. $2010 \mathrm{r}$.

5. Belozerov H. A. Vubor ustavok ammyachnыkh hazosyhnalyzatorov. Kholodylnaia tekhnyka. 2006. № 5. S. $34-37$

6. DP «Ukrkhimtransamiak» pochav obstezhennia stanu mahistrali amiakoprovodu URL: https://infoindustria.com.ua/dpukrhimtransamiak-pochav-obstezhennya-stanu-magistrali-amiakoprovodu/

7. Kak rabotaet sambi dlynnыi v myre ammyakoprovod? URL: https://www.popmech.ru/technologies/254552-kak-rabotaetsamyy-dlinnyy-v-mire-ammiakoprovod/

8. Bondarenko V. L. Perspektyvы poluchenyia redkykh hazov yz otduvochnыkh potokov proyzvodstva ammyaka. Kholodylnaia tekhnyka. 2007. № 2. S. 5 -9.

\section{Spatar O.V.}

Features of functioning of the ammonia pipeline in structure of pipeline transport of the Nikolaev region.

In the article the features of functioning of ammonia pipeline in the structure of pipeline transport of the Nikolaev area are investigated. The analysis of ecological safety and reliability of operation of the linear part of the main ammonia pipeline of the enterprise "Ukrhimtransamiak". It is determined that for ensuring safe modes of operation of the main ammonia pipeline, an automated 
control system for the technological process of transportation of liquid ammonia based on electronic control and microprocessor equipment is provided.

The author noted that modernization is a costly matter that requires billions of hryvnia, but after achieving the primary goals of modernization of the production component of the industry, we can talk about the profits that can be obtained in the future. The author affirms the idea that in 2020 the Nikolaev area sets itself extremely important task - to turn Mykolaiv region on the region of steady economic growth on the basis of the innovative industry, the developed transport and logistic complex, the important food center of the country with ecological, highly effective agriculture, comfortable and safe edge where there are all conditions for all-round development of the person. This will be facilitated primarily by the development of the ammonia pipeline.

The article noted that the introduction of innovative technologies, introduction of energy saving systems, solar and wind generators at the company as one of the components reducing the cost of pumping, will contribute to the development of the ammonia. The surplus electricity produced is an additional source of revenue from green tariff sales. It is allocated that in the territory of the Nikolaev area a number of projects on construction of solar power plants is realized. The introduction of solar and wind generators will lead to additional jobs.

It is concluded that the introduction of innovative actions, innovations in the implementation of energy saving systems, the use of solar and wind generators in pipelines, especially with maintenance of the ammonia pipeline, as one of the components of reducing the cost of pumping, will promote the transport industry in general and Mykolaiv region in particular. It will help to develop the Nikolaev area as the center of steady economic development, and growth of release of cheaper ammonia will promote intensive development of agricultural sector.

Key words: development of pipeline transport, transportation of ammonia, main ammonia pipeline, regional features.

Дата надходження до редакції: 29.08.2019 p. 